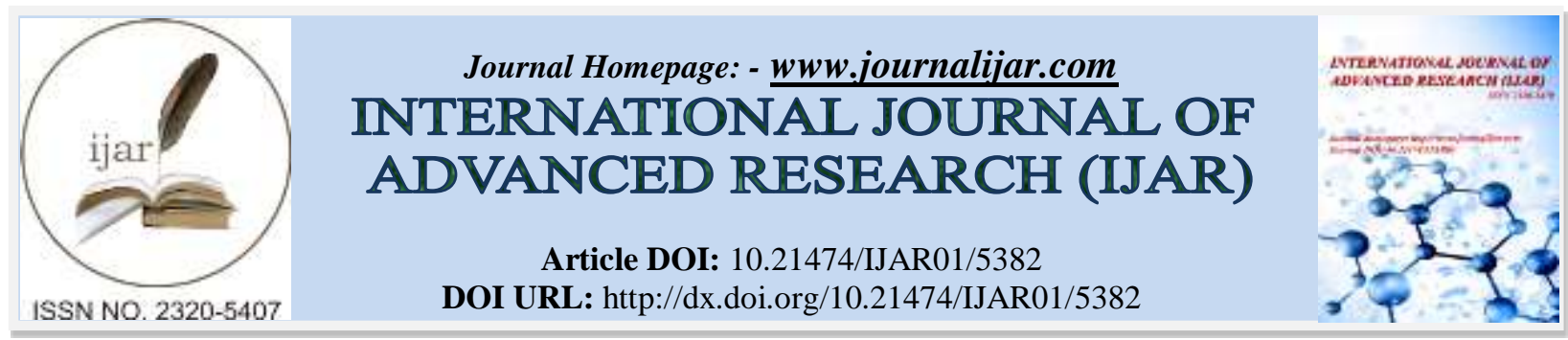

RESEARCH ARTICLE

\title{
AWARENESS PATTERN REGARDING HIV/AIDS AMONG STUDENTS OF GHAZIABAD DISTRICT OF UTTAR PRADESH.
}

Vimal Arya ${ }^{1}$ and Vinod Sharma ${ }^{2}$.

1. Assistant professor, Department of Community Medicine, MLBMC, JHANSI.

2. Post Graduate, Department of Community Medicine, MLBMC, JHANSI.

\section{Manuscript Info}

\section{Manuscript History}

Received: 09 July 2017

Final Accepted: 11 August 2017

Published: September 2017

Key words:-

knowledge, awareness, HIV, AIDS.

\begin{abstract}
Introduction: Human Immunodeficiency Virus (HIV) is today prevalent in all parts of the world and India with no cure or vaccine as of now in sight for HIV/AIDS, knowledge about prevention of the disease still remains the mainstay of containing this dreaded disease.

Objective: To assess the actual status of knowledge and awareness towards HIV/AIDS.

Materials and Methods: A community based cross sectional study was conducted in Santosh Medical College, Ghaziabad Medical, ParaMedical\& Other technical institutes in Ghaziabad(U.P.) for a period from February 2016 to August 2016. A total of 300 students were studied. Data were collected through self administered, well designed pre-tested and close ended questionnaire. Appropriate statistical analysis was done using Epi-info software.

Results: colleges maximum no. of the students was between less than 20 years' age (59.16\%) followed by students between 20 - 25 years' age group (34.16\%). About mode of transmission multiple sex partner 78.83\% about blood transfusion, $81.91 \%$ about homo sexuality knowledge about correct mode of transmission is slightly lower $55.16 \%$.

Conclusion: The preventive effort must focus on increasing awareness of the risks of heterosexual transmission of HIV for people in dating relationship and on strengthening sexual communicating skills with no patterns.
\end{abstract}

Copy Right, IJAR, 2017,. All rights reserved.

\section{Introduction:-}

According to estimates from UNAIDS, 33.3 million people were living with HIV at the end of 2009 and 2.6 million people are newly infected worldwide. UNAIDS reported the changes in incidence rate from 2001 to 2009 among selected countries. It is estimated that 15 million people living with HIV are mostly from lower and middle income countries. The annual number of AIDS-related deaths globally has been decreasing due to the significant scaling up of ART over the past few years. The estimated number of people who died from HIV-related illness in 2009 was 1.8 million [1]. Providing young people with basic AIDS education enable them to protect themselves from becoming infected. Young people are often particularly vulnerable to sexually transmitted HIV, and to HIV infection as a result of drug-use [2]. Acquiring knowledge and skills encourages young people to avoid or reduce 
behaviors that carry a risk of HIV infection [3]. Even for young people who are not yet engaging in risky behaviors, AIDS education is important for ensuring that they are prepared for situations that will put them at risk as they grow older [4] The college going students of NCR are thought to be more enlightened towards HIV infection but they also are apparently more under the influence of western culture and don't shy away from indulging or experimenting in risky sexual behavior. That is why we have planned the present study to assess the actual status of their knowledge, attitude and practice towards HIV/AIDS.

\section{Material And Methods:-}

A community based cross sectional study was conducted in department of Community Medicine Santosh Medical College, Ghaziabad Medical, Para-Medical\& Other technical institutes in Ghaziabad(U.P.) for a period from February 2016 to August 2016. All the students enrolled in medical para-medical and other Technical institutes in district Ghaziabad(U.P.)_Students of selected medical, paramedical \& other technical institutes in Ghaziabad (U.P.)

\section{Sample Size:-}

According to NFHS (2005-2006) average age of comprehensive knowledge regarding HIV/AIDS among students of medical, para-medical and other technical institutes is 25\% [5]. Taking confidence limit of 95\% and required precision of $10 \%$, we calculate the sample size by the formula-

n=z.z.p.q/L.L

$\mathrm{n}$ is the desired sample size

$\mathrm{p}$ is prevalence of knowledge, attitude and practice regarding HIV/AIDS in youths.

$\mathrm{p}=25$

$\mathrm{q}=100-\mathrm{p}$

$\mathrm{L}=5 \%$

Substituting all the values we get $\mathrm{n}=\mathbf{3 0 0}$

4 institutes were included so sample size increased to 1200. From each institute 300 students.

\section{Inclusion criteria:-}

1. Students of selected professional institutes in Ghaziabad district.

2. Students who are ready to give consent.

\section{Exclusion criteria:}

1. Faculty of professional institutes.

2. Students who are not ready to give consent.

3. Students who gave incomplete responses.

Data were collected through self administered, well designed pre-tested and close ended questionnaire.

\section{Results:-}

Table No-1:-General Distribution Of Students According To Age Andsex.

Table No.1 reveals that among all students from professional colleges maximum no. of the students were between less than 20 years' age (59.16\%) followed by students between 20 -25 years age group (34.16\%) students between 25-30 years age were (6.41\%). Among 1200 students male students were $868(72.33 \%)$ and female students were $332(27.66 \%)$.

\begin{tabular}{|l|l|l|l|}
\hline AGE GROUP & MALE & FEMALE & GRANDTOTAL \\
\hline Less than20 & 550 & 160 & $710(59.16 \%)$ \\
\hline $20-25$ & 270 & 140 & $410(34.16 \%)$ \\
\hline $25-30$ & 45 & 32 & $77(6.41 \%)$ \\
\hline $30-35$ & 03 & 00 & $03(0.25 \%)$ \\
\hline TOTAL & $868(72.33 \%)$ & $332(27.66 \%)$ & 1200 \\
\hline
\end{tabular}

Table 2:-Knowledge About Mode Of Transmission.

\begin{tabular}{|l|l|l|}
\hline \multirow{2}{*}{ MODE OF TRANSMISSION } & TOTAL & \multirow{2}{*}{$\begin{array}{l}\text { PERCENTAGE } \\
(\%)\end{array}$} \\
\cline { 2 - 3 } & $\mathrm{n}=1200$ & 78.83 \\
\hline
\end{tabular}




\begin{tabular}{|l|l|l|}
\hline Mother's to new born & 840 & 70 \\
\hline Mosquito bite & 386 & 32.16 \\
\hline Blood transfusion & 983 & 81.91 \\
\hline Shaking hand & 242 & 20.16 \\
\hline Homo sexual & 662 & 55.16 \\
\hline Sharing utensils & 313 & 26.08 \\
\hline Sharing Toilets & 236 & 19.66 \\
\hline Hugging & 374 & 31.16 \\
\hline Kissing & 512 & 42.66 \\
\hline Contaminated needles \& syringes & 898 & 74.83 \\
\hline Don't know & 00 & 00 \\
\hline
\end{tabular}

Table No. 2 shows that responses of correspondents were correct in majority about multiple sex partner 78.83\% about blood transfusion, $81.91 \%$ about homo sexuality knowledge about correct mode of transmission is slightly lower $55.16 \% .31 .16 \%$ \& $42.66 \%$ students wrongly attributed hugging and kissing as a mode of transmission and $32.16 \%$ wrongly attributed mosquito bite as a mode of transmission. $74.83 \%$ students reported $\mathrm{I} / \mathrm{V}$ needles and syringes as a mode of transmission.

Figure 1:- Knowledge About Causative Agent.

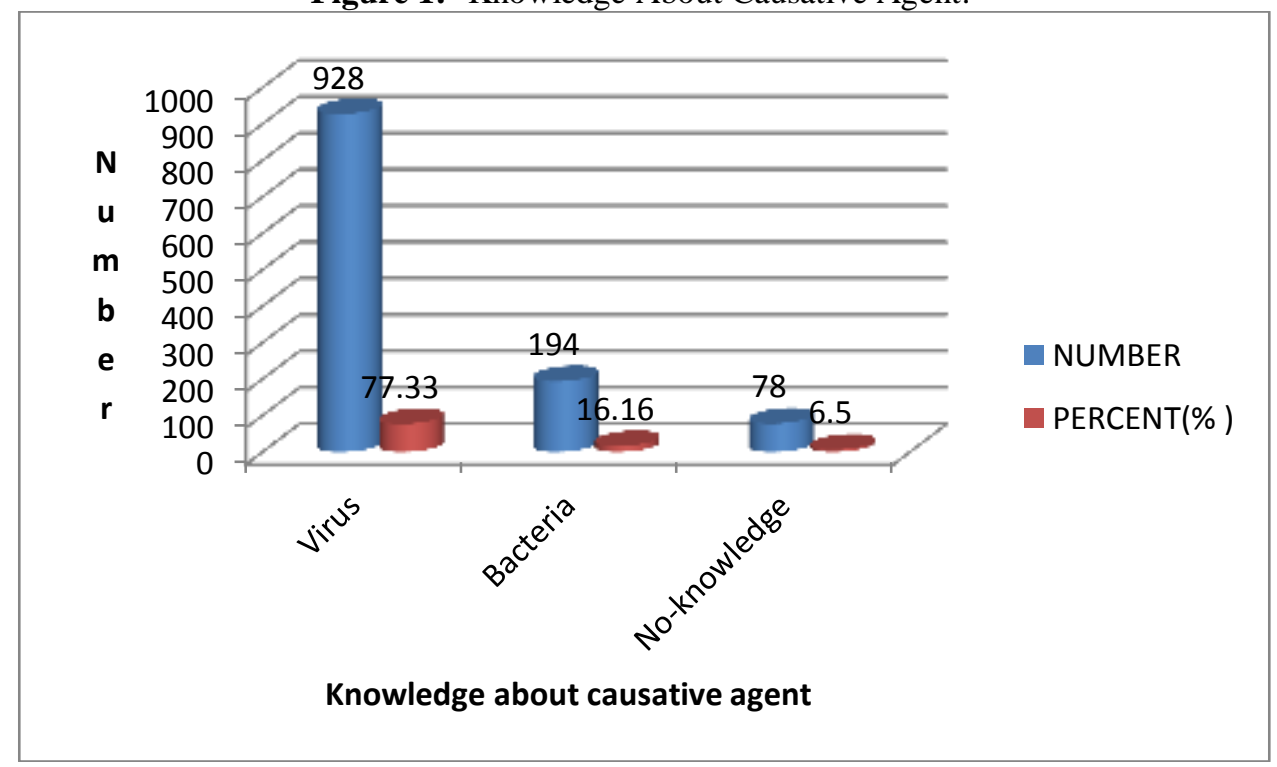

Figure 1 reveals that viral etiology was opined by $77.33 \%$ students. Bacterial etiology was reported by $16.16 \%$ students.

Table 3 :- Knowledge About High Risk Group.

\begin{tabular}{|l|l|l|}
\hline HIGH RISK GROUP & $\begin{array}{l}\text { NUMBER } \\
\mathbf{n = 1 2 0 0}\end{array}$ & PERCENT (\%) \\
\hline PROSTITUTE & 929 & 77.41 \\
\hline $\begin{array}{l}\text { HAVING SEX WITH MULTIPLE } \\
\text { PARTNER }\end{array}$ & 980 & 81.66 \\
\hline HOMO SEXUAL & 676 & 56.33 \\
\hline I/V DRUG USER & 502 & 41.83 \\
\hline PRESENCE OF STD & 536 & 44.66 \\
\hline DON'T KNOW & 00 & 00 \\
\hline
\end{tabular}

Table No 3 reveals that comparatively higher no. of students were able to identify high risk group among prostitute $77.41 \%$, multiple sex partners $81.66 \%$, STD patients $44.66 \%$, homo sexual 56.33 and I/V drug users 41.83 
Table 4:- Knowledge About Symptoms And Outcome Of The Disease.

\begin{tabular}{|l|l|l|}
\hline SYMPTOMS & $\begin{array}{l}\text { NUMBER } \\
\mathbf{n = 1 2 0 0}\end{array}$ & PERCENT (\%) \\
\hline PERSISTENT FEVER & 940 & 78.33 \\
\hline WEIGHT LOSS & 880 & 73.33 \\
\hline PERESISTENT DIARRHOEA & 501 & 41.75 \\
\hline ENLARGEMENT OF GLANDS & 380 & 31.66 \\
\hline DON'T KNOW & 00 & 00 \\
\hline OUTCOME OF THE DISEASE & & \\
\hline CURABLE & 276 & 23 \\
\hline IN-CURABLE & 924 & 77 \\
\hline DON'T KNOW & 00 & 00 \\
\hline
\end{tabular}

Table 4 shows that answers about symptomatology of AIDS reveals that persistent fever is a symptom quoted by majority of students $(78.33 \%)$ followed by weight loss $(73.33 \%)$ than persistent diarrhoea and enlargement of glands respectively $(41.75 \%, 31.66 \%)$, also reveals that regarding curability of AIDS correct answer was given by $23 \%$.

\section{Discussion:-}

In present study regarding general information of students most of the students were of age group less than $20 \mathrm{yrs}$ $(59.16 \%)$ followed by $20-25 y r s(34.16 \%)$ and among whole 1200 respondents $72.33 \%(868)$ were male and 27.66\%(332) were female. In this study respondents stated Blood Transfusion (81.91\%) mother's to new born (70\%), multiple sex partners (78.83\%), homosexuality (55.16\%), unsterilized needles $(74.83 \%)$, indicate average level of knowledge about correct mode of transmission of AIDS. In a study by Srivastavaet al found that $96 \%$ agreed to transmission via blood transfusion, and from infected mother to new born [6].In his study LalPanna et al found that majority of students $(87.9 \%)$ quoted sexual contact, and (81\%) sharing of unsterilized syringes and needles, (70.8\%)infected mother to her baby as a mode of disease transmission. Regarding incorrect modes of transmission in present study students stated mosquito bite (32.16\%), shaking hand (20.16\%), sharing utensils (26.08\%), hugging (31.16\%), sharing toilets (19.66\%) and kissing (42.66\%), as a possible mode of transmission. This indicates a higher degree of misconception about disease transmission is still among population [8]. In an another study Das et al, found that $20 \%$ medical students and $70 \%$ of general college students opined, shaking hand and mosquito bite as a possible mode of transmission [9]. In a study on adolescents, Bahulekeret al, observed that $40.6 \%$ of respondents stated physical contact in school or house could transmit AIDS and 25.5\% replied that AIDS is an insect bite [10]. Saini et al, observed that $70 \%$ of population of $15-45$ years of age quoted kissing and $20 \%$ as sharing of food and clothes of AIDS patient as a possible mode of spread [11]. In present study having sex with multiple partners was the most common high risk group as quoted by $81.66 \%$ students. Homosexuals (56.33\%) students stated as a high risk group. Prostitute or other sex workers is opined by about $77.41 \%$. Odujinrinet al, found that only $54.6 \%$ and $51.5 \%$ identified homosexuals and $\mathrm{I} / \mathrm{V}$ drug users being at higher risk [12].

\section{Conclusions:-}

Among all respondent's predominance of age group of 15-20 years (59.16\%) was observed. The most common vulnerable age group was youth as stated by $71.66 \%$. Regarding correct mode of transmission of HIV/AIDS multiple sex partners was stated as common mode by $81.66 \%$. Blood transfusion was quoted by $81.91 \%$ and mothers to new born $70 \%$. The most common incorrect mode of transmission was hugging $31.16 \%$; kissing $42.66 \%$ and mosquito bite $32.16 \%$ as reported by students. The most common narrated mode of getting the disease was acquired $73 \%$ hereditary $21.5 \%$ and both $5.5 \%$ as stated by students. The most common causative agent is virus as stated by $77.33 \%$ students. Majority of student $78.33 \%$ stated persistent fever,73,33\% stated weight loss as a symptom of AIDS. The least common symptom was enlargement of gland $31.66 \%$. The preventive effort must focus on increasing awareness of the risks of heterosexual transmission of HIV for people in dating relationship and on strengthening sexual communicating skills with no patterns.

1. Aggressive approach to make the public thoroughly aware by:

2. Seminars, talks and debates.

3. Dramas, contests, street and theatre plays.

4. Exhibition of cartoons, photos and painting. 
Conflict Of Interest:-none declared.

Acknowledgement:- authors presents their gratitude towards all the participants as well as head of the department of community medicine and internal medicine.

\section{References:-}

1. UNAIDS (2010)'UNAIDS report on the global AIDS epidemic'.

2. UNESCO ; May 2009 'A strategic approach :HIV \& AIDS and education'.

3. Paul- Euhohimen-V-A. et al. (2008), "A systematic review of school-based sexual health."

4. UNESCO,Director-General(2008),"Why are we still failing our young people?".

5. NFHS-III: National family health survey 2005-2006.

6. Srivastava V.K., Nirupam S and Chandra R. : AIDS awareness amongst school teachers ; CARC calling, 5, 1992:22-23.

7. Aggrawal. A. K., Kumar R.: (1996) Awareness of AIDS among school children in Hariyana; Indian J. Pub. Health 1996, 40:38-45.

8. LalPanna, Kumar Awdhesh, Ingle G.K., GulatiNeena: Knowledge and attitudes of university students regarding HIV/AIDS: An urban-rural difference; J. Comm. Dis., No.-26:186-191.

9. Das Jogesh, Baihyon B.R.: Awareness of AIDS among students; The Assam tribute, Dec1,1994.

10. Bahulekar P.V., Garg B.S.: AIDS awareness in school children; JMGIMS, Vol-1,1996.

11. Saini Ravi, Bharti R., Sharma A. K. \& Sharma Dinesh: Evaluation of AIDS awareness amongst OPD patients of civil hospital, Amritsar; HIV/AIDS research in India (1992): 195.

12. Odujinrin O M, Adgoke O A.(1995) AIDS awareness and blood handling practices of healthcare workers in Lagos, Nigeria; Eur. J. Epid.1995 Aug.;11:425-430. 